\title{
KORBAN SANTET DALAM PERSPEKTIF ANTROPOLOGI KESEHATAN DAN HUKUM ISLAM DI KABUPATEN PAMEKASAN
}

\author{
Abdul Mukti Thabrani \\ Jurusan Syari'ah dan Ekonomi STAIN Pamekasan, Jln. Pahlawan KM. 04 \\ Pamekasan
}

\begin{abstract}
Abstrak
Semakin marak berita-berita dan juga cerita dari orang-orang tentang pengalaman baik bagi dirinya sendiri mau pun teman, kenalan dan keluarga mereka tentang santet, sihir, tenung dan "saudarasaudaranya" atau pengaruh ilmu hitam yang "dikirimkan" oleh seseorang kepada orang lain. Tulisan berikut ingin mengungkap berbagai konsep, pendapat, dan pemahaman arti santet yang ada dalam kehidupan masyarakat dengan fokus masalah persepsi korban santet terhadap penyakit akibat santet yang dialaminya, pola-pola kepercayaan serta pengobatan yang dilakukan oleh para informan dan keluarganya, serta perspektif hukum Islam memandang berbagai pengobatan santet di masyarakat.
\end{abstract}

\section{Kata Kunci :}

Korban Santet, Antropologi Kesehatan, Hukum Islam

\section{Pendahuluan}

Perbincangan dan wacana seputar santet, atau ilmu hitam secara umum, tidak pernah mencapai kata jenuh, malah semakin modern, semakin banyak saja yang memburunya. Semakin marak berita-berita dan juga cerita dari orang-orang tentang pengalaman baik bagi dirinya sendiri mau pun teman, kenalan dan keluarga mereka tentang santet, atau pengaruh 
ilmu hitam yang "dikirimkan" oleh seseorang. Kabar terbaru yang menjadi pemberitaan di berbagai media massa adalah pengakuan aktor kawakan Adi Bing Slamet yang merasa disantet oleh "mantan gurunya" Eyang Subur. Perbincangan tentang santet juga semakin ramai dengan adanya draft undang-undang yang disusun DPR RI terkait fenomena santet. Namun persoalannya hingga saat ini belum ada definisi yang utuh tentang santet.

Penelitian ini ingin mengungkap berbagai konsep, pendapat, dan pemahaman arti santet yang ada dalam kehidupan masyarakat, terutama dari hasil pengalaman individu yang "merasa" pernah kena santet. Penelitian ini akan disajikan dengan model studi pengalaman individu (life history) bagi para korban santet baik berupa gejala-gejala, interpretasi, penanggulangan melalui tindakan-tindakan antisipasi, kuratif dan preventif yang dilakukan secara keagamaan, tradisional dan metafisis karena penyakit akibat santet tidak dapat disernbuhkan secara medis modern. Penyakit karena sebab supranatural yaitu suatu dunia gaib yang ada di luar batas pancaindera dan di luar batas akal manusia. Dunia gaib itu didiami oleh mahluk-mahluk dan kekuatan baik dan jahat. ${ }^{1}$

Kekuatan jahat itulah yang sering digunakan untuk mencelakakan manusia, diantaranya tindakan para dukun sihir yang memanfaatkan kekuatan supranatural jahat ini. Sihir (tenung) seperti halnya pengobatan pada umumnya berada di tangan para ahlinya. Kalau orang ingin menenung seseorang, ia harus menggunakan jasa seorang dukun untuk melakukannya. Guna melaksanakan tenung, tawaran harga mempengaruhi sifat dari tenung tersebut. Semakin jauh jarak antara orang yang akan ditenung dengan penyakit relatif berat, tentu saja dengan dituntut pembayaran yang tinggi. Satu-satunya pertahanan terhadap tenung adalah mencari dukun yang lebih baik, yang

${ }^{1}$ Koentjaraningrat, Beberapa Pokok Antropologi Sosial, (Jakarta: Dian Rakyat, 1967),hlm 218-219. 
kekuatan spiritualnya lebih besar daripada dukun yang digunakan lawan untuk menenungnya. ${ }^{2}$

Pertempuran para dukun dalam medan mistik, kemudian akan terjadi kalau dukun yang digunakannya memang lebih kuat daripada lawannya, ia akan mengembalikan magi itu kepada lawannya, dan ia pun akan jatuh sakit seperti yang semula diharapkan pada orang yang ditenungnya. Dalam kedua kasus itu, kedua dukun itu tetap tidak akan terkena, seperti halnya dua orang pengacara yang bertanding dalam suatu perkara perdata ${ }^{3}$, Magnis Suseno menyatakan bahwa fakta ilmu hitam menggunakan kekuatan-kekuatan gaib untuk merugikan orang lain, hampir tidak ada yang meragukannya. Kekuatan yang diperoleh melalui pengalaman mistik dapat dipergunakan untuk tujuan baik dan tujuan yang jahat. Kekuatan itu tidak hanya memberi kemampuan untuk menyembuhkan, melainkan juga untuk membuat orang lain menjadi sakit. Di mana pun orang takut terkena sihir atau tenung, bagaimana misalnya dia sendiri atau anggota keluarga mereka menjadi korban praktik-praktik hitam itu.

\section{Seputar makna dan modus santet}

Ilmu hitam merupakan bentuk kelakuan asosial yang dalam kesadaran Jawa paling erat diasosiasikan dengan apa yang disebut jahat. Oleh karena itu, praktik ilmu hitam dikutuk keras. Ilmu hitam merupakan kekuatan batin yang menyeleweng dan justru karena pamrih yang melekat padanya lama-lama akan meniadakan diri sendiri. Ilmu hitam pun aklirnya merupakan tanda ketololan. ${ }^{4}$. Semua orang Jawa agaknya berpendapat bahwa ada dua jenis penyakit yang

${ }^{2}$ CliffordGeertz, Abangan, Santri, Priyayi dalam Masyarakat Jawa, (Jakarta: Pustaka Jaya,1981), hlm.144.

${ }^{3}$ Ibid.

${ }^{4}$ Clifford Geertz, "Curing, Sorcery and Magis in a Javanese Town" dalam Culture, Disease, and Healing, David Landy (ed.), (New York: Macmillan Publishing Co. Inc.,1991),hlm. 182,183-186 
pokok: satu, jenis yang biasa ditemukan sebab-sebab fisiknya dan bisa disembuhkan dengan pengobatan dokter yang dididik secara Barat, yang kedua adalah penyakit yang tidak bisa ditemukan sebabnya secara medis, tetapi si pasien masih saja sakit. ini merupakan jenis penyakit yang hanya mampu diobati oleh para dukun. ${ }^{5}$

Istilah santet kadang-kadang juga dipakai untuk menyebut praktik memasukkan benda-benda asing ke perut korban, tetapi sesungguhnya, ia merupakan satu jenis sihir di mana dukun harus mendekati si korban sendiri dan merabanya dengan biji-biji lada (atau sejenisnya) sambil berkali-kali membaca mantra dalam hati tanpa bersuara, si korban kemudian akan terkena diare yang tidak bisa diobati. Jenis sihir lainnya (semua dalam pola yang serupa) yaitu kemampuan membuat orang datang ke suatu tempat yang ditentukan, bertentangan dengan kemauannya sendiri disebut gendam; dan berbagai jenis magi cinta untuk menarik seorang laki-laki atau perempuan yang disebut guna-guna. Selain itu, ada juga magi pencuri barang-barang yang berharga, disebut sirep. Ada lagi sihir yang memaksa si korban melakukan apa saja yang diperintahkan; disebut nuraga. ${ }^{6}$

Dalam harian BERNAS terbitan 11 Oktober 1998 halaman 2, paranormal Bambang Yuwono menjelaskan bahwa kekuatan santet sarnpai 40 hari. Selanjutnya, pengertian santet menurut dia, tujuannya adalah mematikan atau melumpuhkan. Paranormal akan melakukan hal itu asal diberi imbalan yang cukup. Pengertian santet itu sendiri minta bantuan pada roh sesat untuk membunuh atau mencelakakan orang lain. Kalau tidak ada bantuan roh sesat, manusia tidak bisa melakukan. Orang yang main-main dengan santet karena sempitnya pengalaman, banyaknya perkara dan susahnya mencari nafkah.Sementara pendapat masyarakat menyebutkan selain

5Ibid.,hlm.131.

'Ibid.,hlm.146-7. 
yang disebutkan oleh Barnbang Yuwono di atas, bahwa masalah cinta dan cemburu, iri karena kariernya orang lain yang dianggap rivalnya menjadi sebab seseorang menyantet "lawannya". Hal-hal tersebut sebenarnya karena kurangnya iman seseorang sehingga dirinya lebih mudah dikuasai oleh setan.

Dendam yang lebih bersifat subyektif menimbulkan dorongan amarah yang tidak terkendali dan secara diam-diam orang yang dendam itu melalui jalan pintas berusaha mencelakakan atau "membunuh lawannya" secara tidak terangterangan. Jadi sudah ada bibit kebencian, oleh karena itu sihir cenderung untuk dipergunakan kepada para tetangga, teman, kerabat dan kenalan yang cukup dekat. Dukun yang dipakai bisa orang jauh, dan karena itu menyerang seseorang yang tinggal jauh dari tempat upacara dilakukan tetapi pencetus tindakan itu selalu seorang yang berdekatan. Sihir selalu dipraktikkan karena alasan khusus, tidak pernah karena kedengkian yang ringan. Tenung adalah suatu perbuatan mistik pula. $^{7}$

Dalam sistem medis modern, peranan kebudayaan dapat membantu menjelaskan kondisi sakit dan sehat. Definisi keadaan tubuh sebagai suatu symptom (gejala) atau sebagai suatu masalah, adalah bagian dan suatu proses sosial itu sendiri. Bila ada proses seleksi dan definisi yang hanya memusatkan perhatian pada alasan deviasi (studi etiologi) dan mengabaikan apa yang menyebabkan penyimpangan menurut pandangan individu dan masyarakatnya maka hal ini akan mengaburkan aspek-aspek penting dan pengertian kita mengenai pengobatan dan kontrol penyakit (control of illness) ${ }^{8}$. Namun, dalam sistem medis tradisional, perhatian para

7Ibid.,hlm.149.

8J.K.,Zola, “Kebudayaan dan Symptom: Sebuah Analisa mengenai Keluhan yang Diajukan oleh Para Pasien" dalam Manusia, Kebudayaan, dan Lingkungan (ed. Parsudi Suparlan), (Jakarta: Rajawali, 1984), hlm.146. 
penyembuh justru memusatkan pada sistem medis yang bukan Barat (non-Western medical system) secara mutlak lebih berhubungan dengan kebudayaan masyarakat yang bersangkutan.

Secara tradisional, dalam praktiknya dengan kekuatan spiritual dan penekanan pada elemen. Ada tiga elemen dalam proses pengobatan yaitu obat itu sendiri, mantra, dan kondisi pemberi obat (condition of the peformer). Dalam konteks ini kekuatan batin sang dukun, kemarnpuannya untuk memusatkan pikiran sedemikian rupa, sehingga mantra itu sampai ke telinga Tuhan atau roh kembar yang melindungi si pasien. Cara pengobatan dan sihir di Trobiand, mantra merupakan bagian yang esensial dari apa yang disebut "praktik-praktik magi", sedang di kalangan orang Azasde yang pokok adalah obatnya itu sendiri. Di Jawa, aspek ketiga yaitu keadaan pemberi obat dianggap sebagai elemen yang penting sekali. ${ }^{9}$

Sehubungan dengan praktik santet yang menjadi fokus studi ini, maka pengertian tentang istilah-istilah yang berkaitan dengan santet perlu dibahas di sini. Salah satu usaha mistik yang disebut klenik menurut Magnis Suseno ${ }^{10}$ adalah praktikpraktik jahat yang didorong oleh nafsu-nafsu rendah demi benda-benda dunia dan kekuatan iblis. Klenik merupakan usaha untuk kekuatan batin, tetapi terdorong oleh motif-motif yang tidak murni, yaitu untuk memajukan kepentingankeperitingan egoisnya sendiri. Klenik bersifat egois dan asosial, oleh karena itu harus ditolak. Kemungkinan ilmu hitam menghadapkannya dengan kekuatan-kekuatan yang terhadapnya ia marasa tidak berdaya. Hanya dukun yang sebanding dengan lawannya yang ahli ilmu hitam itu yang dapat menetralisasikan pengaruhnya.

Klenik senada dengan istilah sihir. Menurut Claude

${ }^{9}$ Geertz, Abangan...,hlm.127.

10Ibid. 
Levi Strauss ada tiga faktor kemanjuran sihir. Pertama, kepercayaan tukang sihir itu sendiri terhadap efektivitasnya teknik yang dipakai. Kedua, kepercayaan penderita atau korban terhadap kekuatan tukang sihir. Ketiga, kepercayaan dan harapan kelompok yang berfungsi sebagai semacam bidang penghubung tukang sihir dan korban yang ada lansung, seolaholah sebagai tindakan gaya tarik bumi. Ketiga elemen tersebut "perdukunan yang kompleks dan tidak terpisahkan". Namun keduanya dikelompokkan menjadi dua kutub. satu dibentuk oleh pengalaman mendalam dari dukun dan yang lain oleh konsensus kelompok ${ }^{11}$

Ada beberapa jenis sihir yang berbeda-beda, dan jenis yang paling ganas ada tiga yakni tenung, jengges, dan santet. ${ }^{12}$ Perbedaan dari ketiganya tampak dalam praktik dari masingmasing sihir tersebut. Gejala-gejala tenung adalah misalnya muntah darah, mulas yang nyeri sekali di perut, demam yang naik turun, tanpa sebab yang jelas. Pekerjaan dukun terdiri dari semacam Misa-Hitam yang merupakan Slametan bohongbohongan. Dukun duduk mengucapkan mantra di tengahtengah sajen-sajen yang membentuk setengah lingkaran, sajian makanan untuk roh-roh jahat, memohon kehancuran korbannya. ${ }^{13}$

Sajen terdiri dari sebongkah kemenyan yang utuh dan umumnya menggunakan candu, sekali pun beberapa benda lain yang digemari setan seperti cermin mungkin disertakan juga. Kalau orang bermaksud membunuh korbannya dan tidak sekedar membuatnya sakit, ia harus meremukkan kemenyan itu menjadi butiran kecil-kecil yang kemudian dibungkus dengan kain mori putih, diikat di tiga tempat seolah-olah itu adalah

11Strauss, C.L., Structural Anthropology, (New York: Basic Bool Inc., 1977),hlm.446.

${ }^{12}$ Geertz, Abangan..., hlm.45.

${ }^{13}$ Ibid. 
mayat. ${ }^{14}$

Dalam jengges upacara seperti sajen dilakukan juga, kecuali bahwa beberapa benda seperti paku, rambut, pecahan kaca, dan potongan-potongan besi serta jarum disertakan dalam sajen. Dukun mengucapkan mantra dan memusatkan perhatian pada maksud jahatnya dan dengan demikian mampu membujuk mahkul-mahluk halus agar memasukkan bendabenda itu ke perut si korban, yang akan mendengar letusan mendadak di sekelilingnya dan kemudian jatuh sakit parah. Kadang-kadang sepotong kawat panjang digunakan untuk dimasukkan ke dalam lengan atau kaki si korban, dan dengan demikian membuatnya lumpuh. ${ }^{15}$

Clifford Geertz mengatakan pula bahwa istilah santet kadang-kadang juga digunakan untuk menyebut praktik memasukkan benda-benda asing ke perut korban. Sihir selalu dipraktikan untuk alasan yang spesitik, tidak pernah untuk kedengkian yang ringan. Dengan kata lain, karena orang tersebut yaitu orang yang meminta tolong jasa dukun sihir untuk mencelakakan orang lain dengan dendam kesumat. Kadang-kadang orang yang menjadi sasaran santet, sihir dan guna-guna biasanya tidak menyadari dan tidak tahu.

\section{Sistem personalistik santet}

Menurut Foster dan Anderson salah satu konsep kausalitas penyakit adalah sistem personalistik, di samping ada juga sistem naturalistik. Sistem personalistik adalah suatu sistem di mana penyakit (illness) disebabkan oleh intervensi dan suatu agen yang aktif, yang dapat berupa mahluk supranatural (mahluk gaib atau dewa), mahluk yang bukan manusia (seperti hantu, roh leluhur, atau roh jahat) maupun mahluk manusia (tukang sihir atau tukang tenung). Orang sakit adalah korbannya, obyek dan agresi atau hukuman yang ditujukan

${ }^{14}$ Ibid...,hlm.195.

15Ibid.,hlm.145. 
khusus kepadanya untuk alasan-alasan yang khusus menyangkut dirinya saja. ${ }^{16}$

Menurut Glick yang diacu oleh Foster dan Anderson bahwa inti dari kausalitas dalam sistem-sistem personalistik adalah penyakit disebabkan oleh agen-agen (perantara) yang dengan beberapara cara menjatuhkan kekuatan mereka atas diri para korban mereka. Agen-agen tersebut dapat berupaa mahluk manusia, "manusia super" atau bukan manusia; namun senantiasa dipandang sebagai mahluk yang keras hati, yang tidak bertindak sembarangan melainkan sebagai respons terhadap motif pribadi yang disadari. Agen-agen itu dapat melintasi alam natural dan supranatural. Orang-orang biasa yang dilengkapi dengan keterampilan teknis yang tepat, yaitu tukang tenung, demikian pula berbagai mahluk supranatural yaitu hantu, setan semak-semak dan tukang sihir, semuanya dapat menyebabkan penyakit. Penyakit (illness) berasal dari agen, dan terutama akibat rasa iri. Penyakit dan kematian yang "dini" dianggap berasal dari kekuatan-kekuatan luar atau ilmu sihir. Kepercayaan tentang kausalitas penyakit yang bersifat medis dan kesehatan yang tercatat dalam etnografi klasik tentang masyarakat-masyarakat "primitif'. ${ }^{17}$

Sebagaimana hubungan sebab akibat dalam sistemsistem penyebab penyakit merefleksikan prinsip-prinsip struktur dasar, pola-pola, dan premis-premis dart kebudayaan asalnya, tempat mereka terjalin didalamnya. Etiologi-etiologi personalistik logisnya membutuhkan jenis penyembuh tertentu, seorang shaman atau peramal lain, untuk menentukan bukan hanya penyebab langsung dari suatu penyakit, melainkan juga, yang lebih penting, mencari siapa yang berada di belakang penyebab tersebut. 18

${ }^{16}$ Foster, G.M. dan Barbara Anderson, Antropologi Kesehatan, (Jakarta: UI Press, 1986), hlm. 65-66.

${ }^{17}$ Ibid

${ }^{18}$ Ibid...,hlm.80. 
Menurut Claude Levi Strauss, seorang shaman yang sekaligus berperan sebagai dukun, imam dan penghantar roh orang mati adalah seorang penyembuh magis yang biasanya bekerja dalam keadaan "ekstase" atau "trance", yakni keadaan mental tidak sadarkan diri. Dalam keadaan "trance" ini ia sanggup menuruti kemauannya melepaskan roh dari tubuhnya dan mengadakan perjalanan "dunia bawah" (neraka) untuk mengunjungi dan memanggil roh-roh. Oleh karena itu, shaman menjadi perantara yang bertindak sebagai wahana roh, mampu berkomunikasi dengan roh itu dan mampu menguasainya. Berdasarkan kemampuannya, shaman menawarkan jasa magisnya sebagai dukun. Pada dasarnya, cara penyembuhan shamanistis bersifat verbal, dan biasanya tidak menggunakan cara pengobatan fisis atau kimia. Dalam bukunya yang lain (Antara Alam dan Mitos), Claude Levi Strauss juga membedakan secara tegas antara dukun dan shaman.Dukun (dalam bahasa Inggris: Medicine-man) adalah orang yang ahli dalam penyembuhan penyakit, yang disebabkan oleh roh dan kekuatan-kekuatan gaib, berdasarkan kekuatan batin atas kodrati dan pengetahuan eksperimental pengalamannya. Apabila si dukun perlu memasukkan diri ke dalam keadaan tidak sadar diri (trance) dan memanggil roh-roh pembantu proses penyembuhan maka sebaiknya disebut shaman. ${ }^{19}$

Penyakit, religi dan magi lebih berhubungan dengan sistem etiologi, tampak jelas bahwa kedua sistem etiologi, berkorelasi dengan sistem personalistik. Dalam sistem personalistik, pengorbanan-pengorbanan dan sajian-sajian dimaksudkan untuk berdamai dengan mahluk-mahluk yang bertanggung jawab atas terjadinya penyakit tersebut ${ }^{20}$. Magi dan religi, kedua-duanya masuk dalam bidang sakral, yang dapat diterangkan dengan istilah supranatural.

\footnotetext{
${ }^{19}$ Agus, Cremers, Antara Alam dan Mitos: Memperkenalkan Antropologi Struktural Claude Levi-Strauss, Flores-NTT: Nusa Indah,, 1997), hlm. 144.

${ }^{20}$ Foster dan Anderson, Antropologi Kesehatan,...,81-82.
} 
Ahli Antropologi telah mendefinisikan bermacammacam lambang upacara dalam banyak cara, dan upacara mempunyai dimensi sosial, psikologis dan simbol yang penting. Dalam setting sosial, upacara dengan jelas mengulangi memperhatikan dasar nilai dari masyarakat tersebut, khususnya mengenai hubungan antara orang dan orang, orang dan alam, dan orang kepada dunia supranatural. Hubungan itu merupakan bagian pada fungsi dari kelompok mahluk lain. Berdasarkan pada pemahaman tersebut, antropologi kesehatan mempelajari tentang bagaimana penduduk dalam kebudayaan dan kelompok sosial yang berbeda menjelaskan sebab dari sakit-sehat, tipe perawatan/pengobatan yang mereka percayai dan kepada siapa mereka memalingkan atau memilih penyembuh jika mereka mendapat sakit. ${ }^{21}$

Sihir dan guna-guna telah dikenal sejak lama dalam antropologi. Tidak ada satu pun etnografi akan menjadi lengkap tanpa disediakan diskusi pada fenomena itu dalam masyarakat tersebut, yang tampak menjadi hal yang umum. Perbedaan antara sihir dan guna-guna ditegaskan oleh E.E Evans Pritchard bahwa sihir dihubungkan pada magi "buruk", namun sebaliknya sihir dapat dan banyak dilakukan untuk kemampuan yang "baik" sebagaimana berakhir "buruk"

Menurut Claude Levi Strauss ilmu sihir adalah ilmu gaib "hitam" yang bersifat destruktif dan antisosial dengan satusatunya tujuan adalah kematian. Ilmu sihir merupakan bentuk agresi (karena marah, iri, benci, balas dendam, dan sebagainya) dari jauh dan tanpa menggunakan sarana, menyebabkan kejahatan dan kemalangan yang sering besar sekali,demi tujuan-tujuan yang tidak pantas. ${ }^{22}$

\section{Pandangan Islam tentang Santet}

${ }^{21}$ Helman, Cecil G., Culture, Health, and Illness,(Oxford: ButterworthHeinemann, 1995), hlm. 224-225.

${ }^{22}$ Claude Levi Strauss, structural,...,hlm.145. 
Dalam Islam, seorang yang sakit memang dianjurkan berobat.Para ulama sepakat bahwa Islam membolehkan berobat, dan seorang muslim hendaklah berusaha mendatangi dokter yang ahli, baik penyakit dalam maupun penyakit luar lainnya, untuk diperiksa apa penyakit yang diderita kemudian diobati sesuai dengan obat-obat yang dikenal dalam ilmu kedokteran.Dilihat dari sebab akibat yang biasa berlaku, hal ini tidak bertentangan dengan ajaran tawakkal kepada Allah dalam hukum Islam, karena Allah telah menurunkan penyakit dan menurunkan pula obatnya, ada diantaranya yang sudah diketahui oleh manusia dan ada yang belum diketahui.Akan tetapi Allah ta'aala tidak menjadikan penyembuhannya dari sesuatu yang diharamkan kepada mereka.

Oleh karena itu tidak dibenarkan bagi orang yang sakit mendatangi dukun-dukun yang mendakwahkan dirinya mengetahui hal-hal yang gaib, untuk mengetahui penyakit yang dideritanya. Tidak diperbolehkan pula mempercayai atau membenarkan apa yang mereka katakan, karena sesuatu yang mereka katakan mengenai hal-hal yang gaib itu hanya didasarkan atas perkiraan belaka, atau dengan cara mendatangkan jin, dan meminta tolong kepada jin-jin itu tentang sesuatu yang mereka inginkan. Dengan cara demikian dukun-dukun tersebut telah melakukan perbuatan kufur dan kesesatan.

Rasulullah Saw menjelaskan dalam berbagai haditsnya sebagaimana riwayat berikut : "Barang siapa mendatangi 'Arrof (peramal) dan menanyakan sesuatu kepadanya, tidak akan diterima salatnya selama empat puluh hari"23 Dari Abu Hurairah ra dari Nabi Saw beliau bersabda: "barang siapa yang mendatangi kahin (dukun) dan membenarkan apa yang yang ia katakan maka sungguh telah kafir terhadap apa yang diturunkan kepada Muhammad Saw (HR Abu Dawud)

${ }^{23}$ Sunan Abi Daud, vol 4, Hal: 233, Dar Al-Salam, Riyqah 
Hadits-hadits mulia ini menunjukkan larangan mendatangi 'arrof, kahin dan sebangsanya, larangan bertanya kepada mereka tentang hal-hal yang gaib, larangan mempercayai/ membenarkan apa yang mereka katakan dan ancaman bagi mereka yang melakukannya.

Oleh karena itu, pemerintah wajib mencegah segala bentuk praktik tukang ramal, dukun, dan sebangsanya, dan melarang orang-orang mendatangi mereka.Kepada yang berwenang supaya melarang mereka melakukan praktik di pasar-pasar atau di tempat-tempat lainnya dan secara tegas menolak segala yang mereka lakukan.Hendaknya tidak boleh tertipu oleh pengakuan segelintir manusia tentang kebenaran apa yang mereka lakukan, karena orang-orang tersebut tidak mengetahui tentang perkara yang dilakukan oleh dukun-dukun tersebut, bahkan kebanyakan mereka adalah orang-orang awam yang tidak mengerti hukum, dan larangan terhadap perbuatan yang mereka lakukan.

Rasulullah Saw telah melarang umatnya mendatangi para kahin,'arrof, dan tukang tenung, dan melarang bertanya serta membenarkan apa yang mereka katakan, karena mengandung kemungkaran dan bahaya yang sangat besar pula. Karena mereka adalah orang-orang yang melakukan dusta dan dosa.Hadits-hadits Rasulullah Sawtersebut diatas membuktikan tentang kekufuran para kahin dan 'arrof, karena mereka mengaku mengetahui hal-hal yang gaib dan mereka tidak akan sampai pada maksud yang diinginkan melainkan dengan cara berbakti, tunduk, taat, dan menyembah jin-jin, dan ini merupakan perbuatan kufur dan syirik terhadap Allah SWT. Orang orang yang membenarkan mereka atas pengakuan mereka dalam mengetahui hal-hal yang gaib dan meyakininya, maka hukumnya sama seperti mereka.

Setiap orang yang menerima perkara ini dari orang yang melakukannya, sesungguhnya Rasulullah Saw berlepas diri dari mereka.Seorang muslim tidak boleh tunduk dan percaya terhadap dugaan dan sangkaan bahwa cara seperti yang 
dilakukan itu sebagai suatu cara pengobatan, semisal tulisan Azimat-azimat yang mereka buat, atau cairan timah, dan berbagai cerita bohong yang mereka lakukan. Semua ini adalah praktik-praktik perdukunan dan penipuan terhadap manusia, maka barang siapa yang rela menerima praktik-praktik tersebut tanpa menunjukkan sikap penolakannya, sesungguhnya ia telah menolong dalam perbuatan batil dan kufur. ${ }^{24}$

Oleh karena itu, tidak dibenarkan seorang muslim pergi kepada kahin, tukang tenung, tukang santet dan semisalnya, dan menanyakan kepada mereka hal-hal yang berhubungan dengan jodoh dan pernikahan anak atau saudaranya atau yang menyangkut hubungan suami istri dan keluarga, tentang kecintaan, kesetiaan, perselisihan, dan perpecahan yang terjadi, dan lain sebagainya, karena ini berhubungan dengan hal-hal yang gaib yang tidak diketahui hakikatnya oleh siapapun kecuali Allah SWT.

Santet sebagai salah satu perbuatan kufur yang diharamkan oleh Allah SWT dijelaskan di dalam surat AlBaqarah ayat : 102 tentang kisah dua malaikat : "Dan mereka mengikuti apa yang dibacakan oleh setan-setan pada masa kerajaan Sulaiman (dan mereka mengatakan bahwa sulaiman itu mengerjakan sihir), padahal Sulaiman itu tidak kafir (tidak mengerjakan sihir), hanya setan-setan itulah yang kafir (mengerjakan sihir). Mereka mengajarkan kepada manusia apa yang diturunkan kepada dua Malaikat di negeri Babil yaitu Harut Marut, sedang keduanya tidak mengajarkan sesuatu kepada seorangpun sebelum mengatakan: sesungguhnya kami hanya cobaan maka janganlah kamu kafir, maka

24Syekh Al-Jazairi mengatakan bahwa pelaku santet yang terbukti melakukan praktek santet atau sihir, sehingga menimbulkan korban, dalam Negara atau pemerintahan islam, hukumannya adalah had (dibunuh) atau hukuman mati yang dilakukan oleh Negara, hal ini didasarkan pada hadist al-tirmidzi "had atau hukuman pelaku santet dan perdukunan adalah dibunuh" dan peraturan seperti inisudah dijalankan oleh generasi terdahulu. (lihat: jabir al-jazairi, minhaj al-muslim, Hal: 424, dar al-ulum wal-hikam, madinah, 1998. 
mereka mempelajari dari kedua malaikat itu, apa yang dengan sihiritu, mereka dapat menceraikan antara suami dengan istrinya. Dan mereka itu (ahli sihir) tidak bisa memberi madarat dengan santetnya kepada seorangpun kecuali dengan izin Allah.Dan mereka mempelajari sesuatu yang memberikan madarat kepada mereka dan tidak memberi manfaat, dan sungguh mereka mengetahui bahwa barang siapa yang menukar (kitab Allah) dengan sihiritu, tidak ada baginya di akhirat suatu keuntungan dan amat buruklah perbuatan mereka dalam menjual dirinya dengan sihir itu, kalau mereka mengetahui". (QS Al Baqarah ayat: 102)

Ayat yang mulia ini juga menunjukkan bahwa orangorang yang mempelajari ilmu santet, sesungguhnya mereka mempelajari hal-hal yang hanya mendatangkan mudarat bagi diri mereka sendiri, dan tidak pula mendapatkan suatu kebaikan di sisi Allah SWT.Ini merupakan ancaman yang sangat besar yang menunjukkanbetapa besar kerugian yang diderita oleh mereka di dunia ini dan di akhirat kelak. Mereka sesungguhnya telah memperjual belikan diri mereka dengan harga yang sangat murah, itulah sebabnya Allah berfirman : "Dan Alangkah buruknya mereka yang telah menjual diri mereka dengannya (sihir itu), seandainya mereka mengetahui." (QS : 2 : 102)

Kita memohon kepada Allah kesehatan dan keselamatan dari kejahatan santet dan semua jenis praktik perdukunan yang dilakukan oleh tukang santet dan tukang ramal. Kita memohon pula kepadaNya agar kaum muslimin terjaga dari kejahatan mereka, dan semoga Allah SWT memberikan pertolongan kepada kaum muslimin agar senantiasa berhati-hati terhadap mereka, dan melaksanakan hukum Allah dengan segala sangsinya kepada mereka, sehingga manusia menjadi aman dari kejahatan dan segala praktik keji yang mereka lakukan.

\section{Gejala, tipologi, dan penanggulangan santet}

Foster dan Anderson menjelaskan bahwa sistem-sistem personalistik adalah lebih kompleks, dalam arti bahwa dua tingkatan kualitas atau lebih dapat dibedakan, dan dalam usaha 
penyembuhan, tingkatan-tingkatan harus diperhitungkan. Paling sedikit dapat dibedakan antara agen personal (dukun sihir, hantu, atau dewa), dan teknik yang digunakan oleh agen tersebut (seperti pemasukan obyek, racun, pencurian jiwa, kesurupan, atau ilmu sihir). ${ }^{25}$

Dua tingkatan kausalitas dalam penyembuhan yang tampak dalam gejala-gejala sakit pada penderita dapat dideteksi oleh penyembuh baik dukun, paranormal, maupun kyai pada proses penyembuhan yang dilaksanakan. Dalam studi ini agen personal yang berperan adalah dukun sihir (tukang santet) dan teknik yang digunakan oleh agen tersebut adalah pemasukan obyek penyakit dan ilmu sihir yaitu dengan membaca mantramantra dan sesaji upacara.

Jelas bahwa dari pengalaman semua informan menunjukkan adanya unsur peranan dukun sihir sebagai agen dan teknik agen berupa ilmu sihir (mantra) dan pemasukan obyek penyakit. Pengalaman informan yang mendapatkan sakit dengan gejala panas, sakit kepala (kehilangan keseimbangan), perut dan kaki bengkak, mereka merasakan gejala ini tanpa disadari apa yang menyebabkannya. Mereka merasaksan gejala ini terjadi secara fluktuatif, yaitu dengan tiba-tiba serangan sakit datang, tetapi tiba-tiba pula sembuh sendiri dengan waktu relatif tidak sama. Kadang-kadang gejala itu muncul, namun dalam sekejap sudah sembuh. Kembali muncul, hilang, muncul kembali, dan seterusnya. Nmun ada juga di antara mereka yang merasakan gejala sakit itu terus-menerus.

Dari hasil deteksi penyembuh, penyebab sakit mereka adalah dengan pengiriman mantra oleh dukun sihir sehingga jelas di sini bahwa gejala sakit tersebut akibat adanya agen, yaitu perantara dukun sihir atau tukang santet dan teknik agen dengan membaca mantra untuk menyerang "lawannya" agar sakit. Contoh lain bentuk teknik agen adalah memasukkan

${ }^{25}$ G.M Foster dan Barbara Anderson, Antropologi Kesehatan, (Jakarta: UI Press, 1986),hlm.82. 
obyek ke tubuh "lawannya" sehingga mereka merasakan gejala sakit pada bagian badan tertentu. Bentuk pemasukan obyek ke dalam tubuh seperti yanag dialami DC. Bila dirinci dari pengalaman masing-masing informan, gejala itu muncul sebagai berikut: (a) Pengalaman AB,HB: Gejala serangan santet antara lain: kepala terasa melayang-layang, pusing, pikiran terasa kosong, pingsan dan tidak sadarkan diri, dan perut kejang-kejang; (b) Pengalaman DC: Gejala serangan santet antara lain: muntah darah kental, perut membesar, badan panas tinggi, dari perut keluar paku berkarat, silet, dan pecahan kaca; (c) Pengalaman EF,LM: Gejala serangan santet antara lain: suhu badan panas tinggi, perut membengkak dan terasa sakit, muncul bisul dengan ukuran sangat besar di bibir; (d) Pengalaman GH: Gejala serangan santet antara lain: sakit perut yang luar biasa, perut membesar, kedua kaki bengkak dan terasa sangat berat, pinggang serta punggung belakang terasa sangat kaku; (e) Pengalaman JK: Gejala serangan santet antara lain: dada terasa nyeri dan berat, kepala pusing, pikiran kosong, linglung, sering berbicara sendiri, terkadang marah-marah dan ngomel tidak jelas.

Praktik-praktik santet seperti yang tampak dalam gejalagejala pada informan, ternyata sudah banyak dipraktikkan sejak lama dan sampai sekarang masih juga dialami oleh masyarakat. Praktik supranatural sebagai indikasi ke "kuno"an ternyata justru relatif marak di jaman "modern." Hal ini dapat dibuktikan dengan melihat dan mengkaji melalui sistem personalistik bahwa dalam praktik jengges yang dilukiskan Geertz menyebutkan bahwa praktik itu menggunakan teknik pemasukan benda ke obyeknya yaitu perut korban diawali atau dibarengi bunyi letusan mendadak di sekelilingnya. Letusan ini identik dengan bunyi "dor" yang dilukiskan oleh informan. Disebutkan juga oleh Geertz bahwa kadang-kadang sepotong kawat dimasukkan ke dalam lengan atau kaki korban. Ternyata pernyataan Geertz ini dikuatkan oleh pengalaman HB,DC, jadi gejala-gejala yang dikenali informan (korban) seperti halnya 
yang ditemukan Gerrtz pada waktu lalu. ${ }^{26}$ Oleh karena itu, santet masih pada sistem medis non barat sehingga cocok dikaji melalui sistem personalistik karena memang praktik-praktiknya berorientasi pada mistik, kepercayaan dan supranatural. Yaitu, masyarakat percaya sebab sakit (etiologi) penyakit karena sebab supranatural termasuk dalam sistem etiologi personalistik.

Kenyataan menunjukkan bahwa pada abad modern, sistem ini masih berlaku pula. Sistem personalistik cenderung dihubungkan dangan masyarakat petani dan pra industri, tetapi sampai sekarang, hal itu masih eksis. Ironisnya juga, pada kelompok masyarakat berpendidikan tinggi seperti halnya para informan, musibah melalui santet dialami juga. Sehingga ada sindiran "santet masuk kampus."

Walaupun hampir semua informan dalam menanggapi penyakitnya merasa aneh dengan adanya gejala-gejala tersebut, tetapi mereka mencoba menanggulangi penyakitnya kepada perawatan modern. Hasilnya, sakit yang mereka rasakan tidak sembuh. Sudah menjadi hal umum dalam masyarakat jika mereka atau keluarganya menderita sakit, mereka mencari sumber perawatan yang berganti-ganti jika penyakitnya belum sembuh. Mengapa awalnya informan berobat kepada sistem perawatan modern karena mereka menanggapi sakit dengan pemikiran modern yaitu mereka sakit berobat kepada dokter. Hal ini disebabkan oleh pemahaman awal penyakit itu termasuk berbahaya, seperti gejala panas badan, sakit perut, muntah dan sebagainya.

Sebenarnya gejala-gejala yang dipahami oleh informan dan keluarganya dalah realitas yaitu sakit. Gejala-gejala yang mengawali pada mulanya tidak atau kurang diperhitungkan, sehingga mereka tidak tahu kalau sakitnya karena disantet. Baru setelah mendapat penjelasan dari penyembuhan tradisional (dukun, paranormal) dan kyai mereka merekam

${ }^{26}$ Clifford Geertz, Abangan, Santri, Priyayi dalam Masyarakat Jawa, (Jakarta: Pustaka Jaya, 1981),hlm 145. 
kembali peristiwa yang mengawali sakitnya, sehingga mereka percaya yang mengawali sakitnya adalah sebab supranatural yang berarti sakitnya akibat magic buruk (ilmu hitam).

Menurut Foster dan Anderson bahwa sistem etiologi personalistik dan naturalistik dapat dibedakan berdasarkan teknik-teknik diagnosis. Dalam hal personalistik, diinginkan shaman atau dukun sihir yang mempunyai kekuatan besar untuk dapat mengidentifikasi agen penyebabnya. ${ }^{27}$ Sistemsistem personalistik yang mengenalnya membutuhkan penyembuh yang memiliki kekuatan supranatural atau kekuatan ramalan magis, karena perhatian utama pasien dan kerabatnya adalah "siapa?" dan bukanya " apa?".

Shaman, dengan caranya berkomunikasi langsung dengan alam roh, dan dukun sihir dengan kekuatan-kekuatan magisnya, keduanya menjawab pertanyaan-pertanyaan "siapa" dan " mengapa", merupakan jawaban-jawaban logis terhadap kebutuhan akan konsep-konsep kausalitas ganda. ${ }^{28}$ Dengan mengacu pada pengertian "siapa" dan "mengapa" penyembuh dapat mendiagnosa melalui konsultasi dengan roh halus dengan cara trance, penyembuh kemasukan roh lain yang dapat memberikan penjelasan kepada pasien maupun keluarganya bahwa pasien sakit diguna-guna atau disantet. Seperti kasus AB yang diguna-guna karena masalah cinta; begitu juga JK karena menolak menikahi seorang perempuan; DC karena masalah pemilihan kepala desa; dan EF karena persoalan warisan.

Penyembuh dapat menemukan dan mendiagnosis seseorang yang ada gejala sakit yang disebabkan oleh supranatural. Apa yang didiagnosis oleh penyembuh berdasarkan pada penjelasan mencari tahu "siapa?" dan "mengapa?" secara logika bisa diterima oleh pasien dan keluarganya. Hal ini dapat untuk menepis anggapan "umum"

${ }^{27}$ G.M Foster dan Barbara Anderson,....,hlm.82-83

${ }^{28} \mathrm{Ibid}$ 
bahwa sistem kesehatan non Barat tidak rasional, non konvensional, dan primitif.

Kalau dikembalikan kepada pemahaman bahwa "suatu sistem teori penyakit memberikan rasionalisasi bagi pengobatan..." berlaku dalam semua sistem kesehatan, baik modern maupun tradisional. Jadi dalam sistem kesehatan tradisional pun di dalam mendiagnosis secara hukum logika dapat masuk akal. ${ }^{29}$ Cremers menguatkan pendapat Foster dan Anderson serta hasil penelitian ini bahwa logika pemikiran mistis sama tegasnya dan kritisnya dengan pemikiran positif ilmu pengetahuan. ${ }^{30}$

Di samping sistem teori penyakit yang memberikan rasionalisasi bagi pengobatan, suatu sistem teori penyakit menjelaskan "mengapa?". Disebutkan pula oleh Foster dan Anderson, bahwa sistem teori penyakit tidak hanya mendiagnosis sebab dan memberikan pengobatan yang logis, tetapi yang lebih luas lagi tentang apa yang telah mengganggu hubungan sosial pasien, keseimbangan apakah yang terdapat dalam alam yang telah terganggu dan mengapa, dengan individu tersebut (seperti telah diacu dalam kerangka pemikiran). ${ }^{31}$

Berdasarkan pada teori tersebut dan rumus:

$$
\frac{\mathrm{A}(-)+\mathrm{B}(-)=\mathrm{D}}{\mathrm{C}(-)}
$$

maka kiranya dapat dijabarkan di sini bahwa:

a. Hubungan sosial (hubungan dengan tetangga, teman, dan sebagainya). Apabila hubungan sosial pasien kurang/ tidak baik. [a (-)]

Berdasarkan kasus pengalaman para informan, mereka secara tidak disadari sebenarnya tidak

${ }^{29}$ G.M Foster dan Barbara Anderson,....,hlm. 52

${ }^{30}$ Agus Cremers, Antara Alam dan Mitos: Memperkenalkan Antropologi Struktural Claude Levi-Strauss, (Flores-NTT: Nusa Indah, 1997), hlm.65.

${ }^{31}$ G.M Foster dan Barbara Anderson,....,hlm. 53 
mempunyai " musuh" seperti dijelaskan mereka. Mereka tahu kalau ada orang yang sakit hati, cemburu karena cinta dan masalah karier, setelah kondisi sakitnya didiagnosis oleh penyembuh dan mereka menelusuri peristiwa yang mengawali yaitu sakit secara tiba-tiba, atau terdengar bunyi-bunyi asing, dan semacamnya sebagai peristiwa aneh. Mereka menganalisis bahwa betul mereka disantet karena hubungan sosial mereka dengan orang yang menyantet kurang baik. Di sini ada hubungan tidak baik sepihak, yaitu hubungan yang tidak disadari informan, namun pihak penyantet sangat membencinya (korban/ informan) dan sakit hati karena iri.

b. Kondisi lingkungan (faktor dari luar) kurang/ tidak baik. [c (-)]

Faktor dari luar dimaksudkan adalah di luar dirinya. Di sini dapat dijelaskan sebagai lingkungan pekerjaan (kantor) dan pergaulan. Di antara teman mereka ada yang merasa sakit hati (cemburu, ditolak cinta dan salah paham).

c. Keadaan si pasien (ketahanan pasien terhadap kekuatan setan). [c (-)]

Pada awalnya pasien tidak menyadari adanya sanatet yang dikirim seseorang kepada mereka. Pasien (informan) pada waktu mendapatkan serangan pertama bagi yang disantet lebih dari satu kali merasakan bahwa apabila ada tanda-tanda awal pengiriman santet mereka mengantisipasi dengan banyak cara dan secara teratur membaca ayat-ayat suci al-Qur'an. Dengan cara ini, informan dapat terhindar dari serangan santet. Sebaliknya, bagi informan yang kuat dari serangan santet, mereka tidak akan langsung terkena. Seperti pengalaman $A B$, sebagaimana dikatakan oleh penyembuh $\mathrm{AB}$ bahwa ia cukup kuat 
dari serangan santet. Di samping itu, pengalaman menunjukkan bahwa beberapa informan selamat, terlepas dari santet karena usaha penyembuhan melalui dukun, paranormal, dan kyai.

d. Pasien akan jatuh sakit. (d)

Kenyataan menunjukkan bahwa pada awalnya para informan mengalami [a (-)], dengan tanpa disadari, kemudian kondisi lingkungan kantor (tempat kerja) dan pergaulan mendorong terjadinya santet [b ()]. Keadaan pasien yaitu daya tahan pada kekuatan gaib pada sebagian informan tidak kuat, sehingga mereka mengalami sakit, ada yang ringan, ada yang sedang, dan ada yang sangat berat hingga menyebabkan kematian. Oleh karena itu, logika berpikir masyarakat dalam sistem personalistik dengan sendirinya rasional.

Akhirnya, seiring dengan berjalannya waktu, pengalaman informan dengan berulang kali diteror dengan santet, sebagian mampu bertahan dan berhasil sembuh karena pengobatan dari dukun, paranormal, atau kyai, dan sebagian lain menyebabkan kematian. Hal ini dapat dilihat dari rumus tersebut bahwa hubungan sosial informan dengan teman tetap tidak baik [a (-)], kondisi lingkungan juga menunjukkan hal yang sama [b (-)], sedangkan daya tahan pasien terhadap kekuatan gaib positif [c $(+)$ ] karena informan telah melaksanakan anjuran untuk membaca ayat-ayat suci al-Qur'an, sehingga mereka tidak mempan oleh santet. Mereka tidak sakit, maka [d(-)].

Kembali lagi diulang disini pernyataan Cremers bahwa pemikiran mistis sama tegasnya dan kritisnya dengan pemikiran positif ilmu pengetahuan. Diagnosis dari para penyembuh hanya berdasarkan meditasi dan analisis gejala justru lebih diutamakan sehingga rumusan di atas cocok untuk digunakan dalam analisis gejala. Rupanya ada semacam perbedaan atau pergeseran cara mendiagnosis dari masa 
lampau dengan masa sekarang. ${ }^{32}$ Walaupun tidak terlalu berbeda, diagnosis dengan metode numerologi (petungan) kurang digunakan oleh penyembuh. Seperti dikatakan Clifford Gerrtz bahwa diagnosis dapat didasarkan pada salah saatu dari ketiga metode atau kombinasi dari ketiganya, yaitu numerologi, meditasi, dan analisis gejala. ${ }^{33}$

Terapi (pengobatan) oleh informan dilaksanakan dengan dua cara. Pertama, mereka mencari perawatan medis modern dengan mendatangi dokter. Ada yang opname, diinfus, pemeriksaan laboratorium dan CT Scan, pemberian obat penenang, obat penghilang rasa sakit, dan semacamnya. Semua informan mula pertama mencari sumber perawatan modern karena gejala penyakitnya menunjukkan gejala klinis yang berdasarkan pengetahuan mereka bahwa gejala sakit itu harus dibawa ke dokter. Hal ini diperkuat pula oleh latar belakang sosial mereka yang telah berpendidikan, bahkan sebagian berpendidikan tinggi. Dengan menggunakan terapi medis modern, tidak satu pun pasien (informan) sembuh sakitnya. Oleh karena itu, pasien (informan) berpaling kepada pengobatan tradisional dukun, paranormal, dan kyai.

Kedua, informan kemudian mencari sumber perawatan tradisional karena penyakit mereka tidak ditemukan sebabnya dan tidak dapat diobati secara medis modern. Hal ini merupakan jenis penyakit yang hanya mampu diobati oleh para dukun. ${ }^{34}$ Di samping itu, jika sudah jelas sebab sakitnya karena disantet orang, pengobatan yang cocok adalah dukun karean sakitnya akibat santet tidak dapat disembuhkan secara medis modern.

Alternatif informan memilih sumber perawatan tradisional atas saran keluaraga, teman, atau tamu yang menegok mereka. Semua informan akhirnya berobat kepada

\footnotetext{
${ }^{32}$ Agus Cremers,...,hlm.65

${ }^{33}$ Clifford Geertz, ....,hlm 148

${ }^{34} \mathrm{Ibid}, \mathrm{hlm} 131$.
} 
perawatan tradisional dukun, paranormal, dan kyai. Sistem yang digunakan oleh dukun yang oleh Claude Levi Strauss disebut shaman. ${ }^{35}$ Karena di dalam praktiknya dengan cara "trance" telah dilakukan masih sama persis dengan yang disampaikan Clifford Geertz. Sepertinya praktik ini masih berlangsung sampai sekarang.

Berbeda dari praktik shaman, paranormal melakukan pengobatan dengan cara meditasi dan doa-doa dalam agama Islam yang dipadukan dengan persyaratan tertentu misalnya pasien disuruh meminum air kelapa muda dan kelapa hijau, meminum air putih yanga telah dimantrai, dan sebagainya. Di dalam melaksanakan persyaratan tersebut, pasien dianjurkan pula membaca doa-doa dalam agama Islam.

Praktik pengobatan dari kyai juga mirip dengan praktik paranormal. Bedanya pada praktik kyai persyaratan ramuan disertai pula, tetapi tampaknya penekanan pengobatan pada bacaan ayat-ayat suci al-Qur'an. Sering-sering kedua praktisi paranormal dan kyai menganjurkan kepada pasiennya untuk selalu membaca ayat-ayat suci al-Qur'an. Saran tersebut dilaksanakan oleh informan baik yang mendapat santet sekali maupun berulang kali. Pengulangan terus menerus untuk membaca ayat-ayat suci al-Qur'an pada waktu- waktu tertentu, informan dapat terhindar dari santet meskipun masih mengalami hal yang sama. Informan selamat dari santet meskipun gejala santet sering muncul.

\section{Variasi Penangkalan Santet}

Allah telah mensyari'atkan kepada hambaNya supaya mereka menjauhkan diri dari kejahatan santet sebelum terjadi pada diri mereka, dan Allah menjelaskan pula tentang bagaimana cara pengobatannya bila ia terjadi pada diri mereka. Ini merupakan rahmat dan kasih sayang Allah, kebaikan dan kesempurnaan nikmatNya kepada hambaNya.

${ }^{35}$ (Cremers dan Santo, 1997: 144) 
Berikut ini beberapa penjelasan tentang usaha menjaga diri dari bahaya santet sebelum terjadi, begitu pula usaha dan cara pengobatannya bila terkena santet, yakni dengan cara-cara yang dibolehkan menurut syara'.

1) Tindakan preventif yakni usaha menjauhkan diri dari bahaya santet sebelum terjadi. Cara yang paling penting dan bermanfaat adalah penjagaan dengan melakukan zikir yang disyariatkan, membaca doa dan ta'awwudz sesuai dengan tuntunan Rasulullah Saw diantaranya seperti di bawah ini :

a) Membaca ayat Kursi setiap selesai salat lima waktu sesudah membaca wirid yang disyariatkan setelah salam atau dibaca ketika akan tidur. Karena ayat kursi termasuk ayat yang paling besar nilainya di dalam alQur'an. Rasulullah Saw bersabda dalam salah satu hadits sahihnya :

"Barang siapa yang membaca ayat kursi pada malam hari, Allah senantiasa menjaganya dan setan tidak akan mendekatinya sampai subuh."

Ayat tersebut dalam surat al-Baqarah ayat 255 yang Artinya :

"Allah tidak ada Ilah( yang berhak disembah) kecuali Dia Yang Maha Hidup lagi terus menerus mengurus makhluqNya, tidak terkena rasa mengantuk dan tidak tidur, kepunyaan-Nya apa yang di langit dan apa yang di bumi. Siapakah yang dapat memberi syafaat di sisi Allah tanpa izinNya? Allah mengetahui apa yang di hadapan mereka dan di belakang mereka, dan mereka tidak mengetahui apa-apa dari ilmu Allah melainkan apa yang dikehendakiNya. Kursi Allah meliputi langit dan bumi.Dan Allah Maha Tinggi lagi Maha Besar."

b) Membaca Surat Al Ikhlas, surat Al Falaq, dan Surat An Naas pada setiap selesai salat lima waktu, dan membaca ketiga surat tersebut sebanyak tiga kali pada pagi hari 
sesudah subuh dan menjelang malam sebelum salat Maghrib, sesuai dengan hadits riwayat Tirmidzi dan Nasa'i.

c) Membaca dua ayat terakhir surat Al Baqarah ayat 285286, pada permulaan malam, sebagaimana sabda Rasulullah Saw: "Barang siapa yang membaca dua ayat terakhir dari surat AlBaqarah pada malam hari, maka cukuplah baginya."

d) Banyak membaca ta'awwudz dengan menggunakan kalimah Allah yang sempurna untuk memohon perlindungan diri dari kejahatan makhlukNya.Hendaklah dibaca pada malam dan siang hari ketika berada di suatu tempat, ketika masuk dalam suatu bangunan, ketika berada di tengah padang pasir, di udara, atau di laut .

e) Sabda Rasulullah Saw:

"Barang siapa singgah di suatu tempat dan dia mengucapkan :(aku berlindung dengan kalimat Allah yang sempurna dari kejahatan apa yang Dia ciptakan) maka tidak ada sesuatupun yang membahayakannya sampai ia pergi dari tempat itu".

f) Membaca do'a di bawah ini masing-masing tiga kali pada pagi hari dan menjelang malam : ${ }^{36}$

"Dengan nama Allah, yang tidak ada yang membahayakan bersama namaNya sesuatupun yang ada di bumi dan di langit, dan Dia Maha Mendengar lagi Maha Mengetaui".( HR Abu Dawud dan Tirmidzi)

Bacaan dzikir dan ta'aawudz ini merupakan sebab yang besar untuk memperoleh keselamatan dan menjauhkan diri dari kejahatan santet dan kejahatan lainnya, bagi mereka yang selalu mengamalkannya secara benar disertai keyakinan yang penuh kepada Allah, bertumpu dan pasrah kepadaNya dengan lapang

${ }^{36}$ Sunan abi daud, vol 5, hal: 237, dar al-ma`rifah, bairut, t.t 
dada dan hati yang khusu'. Bacaan-bacaan seperti ini juga merupakan senjata ampuh untuk menghilangkan santet yang sedang menimpa seseorang, dengan cara dibaca dengan hati yang khusu', tunduk, dan merendahkan diri, seraya memohon kepada Allah agar dihilangkan bahaya dan malapetaka yang dihadapi. Do'a-doa' berdasarkan riwayat yang kuat dari Rasulullah Sawuntuk menyembuhkan penyakit yang disebabkan oleh santet dan lain sebagainya adalah sebagai berikut :

Rasulullah Sawmeruqiyah (menjampi-jampi) dengan bacaan :

Artinya: "Ya Allah Pemelihara manusia, hilangkanlah penyakit dan sembuhkanlah, Engkau Maha Penyembuh, tidak ada penyembuhan melainkan penyembuhan-Mu, penyembuhan yang tidak meninggalkan penyakit". ( HR Bukhori)

Saw:

Do'a yang dibaca Jibril ra ketika menjampi Rasulullah

Artinya: "Dengan nama Allah aku menjampimu, dari segala yang mengganggumu dan dari segala kejahatan setiap jiwa, atau dari mata yang dengki, Allah menyembuhkanmu, dengan nama Allah aku menjampi-Mu."

Hendaklah do'a ini diulang tiga kali.

Pengobatan santet dengan cara lainnya, terutama bagi lakilaki yang tidak dapat berhubungan badan (berjima') dengan istrinya karena terkena santet, dengan cara mengambil tujuh lembar daun bidara yang masih hijau ditumbuk atau diulek dengan batu atau alat tumbuk lainnya, sesudah itu dimasukkan ke dalam sebuah bejana atau wadah, kemudian tuangkanlah air ke dalam wadah itu secukupnya untuk mandi, bacakan ayat kursi ke dalam bejana tersebut, bacakan pula surat Al-Kafirun, Al-Ikhlas, An-Nas dan ayat-ayat penangkal santet yang lainnya 
dalam surat Al-A'raf ayat: 117-119, Yunus ayat : 79-82, Surat Taha ayat : 65-69.

Bacaan surat Taha ayat : 65-69 yang artinya :

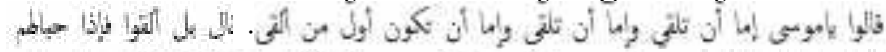

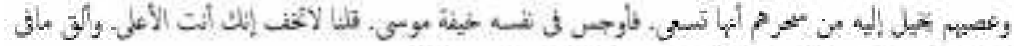

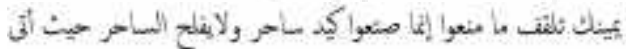

65. (Setelah mereka berkumpul) mereka berkata: "Hai Musa (pilihlah), apakah kamu yang melemparkan (dahulu) atau kamikah orang yang mula-mula melemparkan?"

66.Berkata Musa: "Silahkan kamu sekalian melemparkan". Maka tiba-tiba tali-tali dan tongkat-tongkat mereka, terbayang kepada Musa seakan-akan ia merayap cepat, lantaran sihir mereka.

67. Maka Musa merasa takut dalam hatinya.

68.Kami berkata: "Janganlah kamu takut, Sesungguhnya kamulah yang paling unggul (menang).

69.Dan lemparkanlah apa yang ada ditangan kananmu, niscaya ia akan menelan apa yang mereka perbuat. "Sesungguhnya apa yang mereka perbuat itu adalah tipu daya tukang sihir (belaka).dan tidak akan menang tukang sihir itu, dari mana saja ia datang".

Setelah selesai membaca ayat-ayat tersebut di atas hendaklah minum sedikit dari airnya dan sisanya dipakai untuk mandi.Dengan cara ini mudah-mudahan Allah SWT menghilangkan penyakit yang sedang diderita, dan seandainya masih diperlukan pengobatan seperti ini beberapa kali, boleh saja dilakukan kembali dua kali atu lebih sampai benar-benar hilang penyakitnya.

Cara pengobatan lainnya, sebagai cara yang paling bermanfaat ialah berupaya mengerahkan tenaga dan daya untuk mengetahui di mana tempat santet terjadi, diatas gunung atau di tempat manapun berada dan bila sudah diketahui 
tempatnya, diambil dan dimusnahkan sehingga lenyaplah santet tersebut.

Adapun pengobatan dengan cara-cara yang dilakukan oleh tukang-tukang santet yaitu dengan mendekatkan diri kepada jin disertai penyembelihan hewan atau cara-cara mendekatkan diri lainnya, semua itu tidak dibenarkan karena termasuk perbuatan setan bahkan termasuk perbuatan syirik yang paling besar yang wajib dihindari.

Demikian pula pengobatan dengan cara bertanya kepada dukun 'Arrof tukang ramal dan menggunakan petunjuk sesuai dengan apa yang mereka katakan, semua itu tidak dibenarkan dalam Hukum Islam, karena dukun-dukun tersebut adalah para pendusta dan pembohong yang mengaku mengetaui hal-hal yang gaib dan kemudian menipu manusia.

Rasulullah Saw telah memperingatkan orang-orang yang menadatangi mereka, menanyakan mereka dan membenarkan apa yang yang merekla katakan, sebagaimana telah dijelaskan hukum-hukumnya di bagian awal bab ini.

\section{Doa-doa Penyembuhan Santet menurut Informan}

Adanya tiga macam penyembuh yang dihubungi oleh masing-masing informan secara berbeda menunjukkan bahwa antara paranormal dan dukun (aliran White magic) dan kyai di dalam melaksanakan terapi selalu diikuti dengan serangkaian doa-doa yang harus dibaca oleh pasien (informan).

Berdasarakan penuturan dari pengalaman para informan, doa-doa itu dibaca sebelum, sesudah, atau bebarengan dengan serangkaian upacara penyembuhan seperti telah disebutkan dalam Bab II tentang pengalaman individu. Doa-doa untuk penyembuhan, pasien supaya membaca doa berturut-turut sebagai berikut:
1) Al-Fatihah $1 x$
2) Al-Ikhlas $1 x$
3) An- Naas $1 x$ 
Ayat-ayat di atas dianjurkan dibaca setiap kali selesai salat terutama pada salat maghrib supaya terhindar dari godaan setan dan pengaruh jahat, termasuk santet. Kyai, paranormal dan dukun (white magic) kepada paasiennya berpesan agar jangan lupa membaca ayat-ayat itu supaya terhindar dari pengaruh jahat.

Doa-doa itu harus dibaca berurutan, sebagai berikut:

4) Ayat kursyi 1x:" Allahulailaaha illa huwal hayyul qayyuummu la tkkhudzuhuu sinatuwwalaa nauum, lahuu maa fid samawaati wamaa fila ardli man dhal ladzi yayfa'u 'indahhu illa bi idznih, ya'lamu maa baina aidihiim wa maa khalfahum w laa yuhiituuna bisyaiim min 'ilmihii illa bi maa syaa awasi'a kursiyyuhus samaawaati wal ardli wa laa yauuduhuu hifdzuhumma wa huwal 'aliyyul 'adziim".

Artinya:"Allah tidak ada Tuhan melainkan Dia yang hidup Kekal lagi terus menerus mengurus (makhluk Nya), tidak mengantuk dan tidak tidur. Kepunyaannya Naya apa yang di langit dan di bumi. Siapakah yang dapat memberi syafaa'at di sisi Allah tanpa izin naya? Allah mengetahui apa-apa yang di haadapan mereka dan di belakang mereka, dan mereka tidak mengetahui mengetahui apa-apa dari ilmu Allah melainkan apa yang dikehendaki Naya. Kursi llah meliputi langit dan abumi. Dan Allah tidak merasa berat memelihara keduanya, dan Allah Maha Tinggi lagi Maha Besar".

Anjuran para penyembuh tradisional kepada para pasien dengan membaca al Fatihah karena memang surat tersebut mempunyai khasiat untuk penyembuhan penyakit. Dalam hadist disebutkan bahwa di dalam Surat al-Fatihah terkandung maziyyah atau keistimewaan yang banyak sekali termasuk di dalamnya untuk penyembuhan segala penyakit.Keutamaan Surat al Fatihah adalah seperti sabda Nabi Muhammad Saw: "fatihataul kitab (Surat al Fatihah) itu adalah obat obat dari segala penyakit". Dalam hadis lain disebutkan, "Fatihatul kitab (Surat al Fatihah ) adalah obat dari segala racun. 
Demikian juga khasiat Surat al-Falaq dan Surat an-Naas apabila dibaca masing-masing 41 kali selama tiga hari, lima hari atau tujuh hari berturut-turut, Insya Allah kita akan terhindar dari penyakit yang dibuat syetan atau manusia...Bacaan Surat al Falaq sebagai berikut:"Bismillahirrahmaanir rahiim, Qul a'uudzu bi robbil falaq, min syarri maa kholaq, wa min syaarai ghoosiqin idzaa waqob, wa min syarrin naffasati fil 'uqod, wa min syarri haasidin idzaa hasad." (Katakanlah hai Muhammad aku berlindung pada Tuhan yang memelihara falaq, dari kejahatan sesuatu yang dijadikannya, dan dari kejahatan malam apabila ia gelap, dan dari kejahatan tipuan beberapa tukang santet pada buhulan dan dari kejahatan orang yang menghasut apabila ia menghasut." 37

\section{Penutup}

Penggunaan ilmu hitam adalah suatu tindakan asosial karena tindakan ini merupakan tindakan jahat yaitu dengan sengaja mencelakakan orang lain. Namun pembuktian ilmiah dan hukum sulit diterima, sedangkan fenomena itu jelas merugikan masyarakat. Kadang-kadang karena dorongan emosi, masyarakat menyelesaikan senidiri masalah ini sebagai tindakan yang melawan hukum yaitu main hakim sendiri. Ironisnya justru tukang santet yang "dihukum" oleh masyarakat, bukan kliennya yang jelas-jelas merugikan orang lain.

Pembuktian ilmiah dan tidak ilmiah sebenarnya terletak pada perbedaan perspektif. Perspektif hukum membutuhkan pembuktian ilmiah sebagai barang bukti yang dapat diterima secara indrawi untuk dapat ditentukan salah atau tidak salah, sehingga meskipun praktik santet "jelas" merugikan masyarakat, fenomena ini sementara sulit untuk dimejahijaukan atau dipenjarakan secara hukum.

${ }^{37} \mathrm{HR}$ bukhari Muslim (Shahih Muslim 10/241, Dar- Al-Ma`rifah, Beirut, 1998). 
Lepas dari perspektif di atas, yang menjadi fokus kajian tentang santet adalah salah satu fenomena sosial yang berdampak atau cenderung berhubungan dengan fenomena kesehatan. Berdasarkan studi kepustakaan sejak zaman dahulu masalah santet sudah ada dalam kehidupan masyarakat yang berorientasi pada sistem kesehatan non Barat. Masalah santet cenderung dihubungkan dengan sistem kesehatan tradisional karena memang kehadirannya juga pada sistem tersebut.

Telah banyak dibicarakan dan termasuk pada sistem personalistik kejadian-kejadian sakit karena sebab personalistik yaitu seseorang jatuh sakit karena ada perantaranya seperti setan, manusia, dewa dan sebagainya.Oleh karena itu, santet merupakan salah satu fenomena sosial yang lebih berhubungan dengan orang menjadi sakit. Orang menjadi sakit karena seseorang telah mengirimkan guna-guna melalui tukang sihir/ tukang santet yang bisa berbentuk benda atau binatang seperti pengalaman informan.

Masyarakat yang percaya adanya santet sebagai sebab sakit yang tidak dapat ditemukan penyakitnya secara medis modern, jenis penyakit ini hanya mampu diobati oleh para praktisi tradisional. Temuan Magniz Suseno, Clifford Geertz dan Claude Live Strauss seperti yang dipaparkan di bagian pendahuluan menyebutkan bahwa penyembuhan penyakit karena santet dilakukan dalam model perawatan dukun dan paranormal. Kenyataan menunjukkan pula bahwa pengalaman para informan juga melakukan hal yang sama penyembuhan melalui dukun dan aparanorml. Selain itu, penyembuhan juga dilakukan oleh oleh kyai (secara agama Islam). Dari para penyembuh tradisional ini pun sekarang menggunakan doa-doa dalam agama Islam untuk penyembuhan. baik Magnis Suseno maupun Clifford Geertz tidak menyebutkan peranan kyai dalam menangani penderita yang " diserang" santet. Apakah pada waktu itu belum ada, atau tidak terdeteksi? 
Berbeda dalam perkembangansekarang, doa-doa dalam agama Islam dipergunaakn untuk tindakan preventif dan kuratif baik yang dianjurkan oleh Kyai maupun paranormal seperti yang dilakukan informan untuk membaca ayat-ayat suci al-Qur'an. Namun, praktik dukun (penyembuh tradisional)yang ditemukan dalam kajian ini masih menunjukkan hal yang sama dengan temuan yang dilaporkan Magnis Suseno dan Clifford Geertz. Berdasarkan pada pengalaman para informan, doa-doa dalam al-Qur'an yang dibaca berulang-ulang dapat untuk pengobatan dan pencegahan terhadap santet dan sakit karena "diserang" santet.

\section{Daftar Pustaka}

Abu Bakar, Jabir al-Jazairi, minhajul muslim, Darul Salam, Beirut, 1998

Baal, J. Van., Sejarah dan Pertumbuhan Teori Antropologi Budaya hingga Dekade 1970 (jilid 2), (Jakarta: PT. Gramedia, 1988).

Cremers, Agus, Antara Alam dan Mitos: Memperkenalkan Antropologi Struktural Claude Levi-Strauss, (Flores-NTT: Nusa Indah, 1997).

Foster, G.M. dan Barbara Anderson, Antropologi Kesehatan, (Jakarta: UI Press, 1986).

Geertz, Clifford, "Curing, Sorcery and Magis in a Javanese Town" dalam Culture, Disease, and Healing, David Landy (ed.), (New York: Macmillan Publishing Co. Inc., 1977). Abangan, Santri, Priyayi dalam Masyarakat Jawa, (Jakarta: Pustaka Jaya, 1981).

Hans J, Daeng,., Manusia, Kebudayaan dan Lingkungan, Tinjauan Antropologis,(Yogyakarta: Pustaka Pelajar, 2000).

Helman, Cecil G., Culture, Health, and Illness, Oxford: Butterworth-Heinemann, 1995.

Koentjaranigrat, Beberapa Pokok Antropologi Sosial, (Jakarta: Dian Rakyat, 1967). 
Kebudayaan, Mentalitas, dan Pembangunan, (Jakarta: Gramedia, 1994).

Kuntowijoyo, Perubahan Sosial dalam Masyarakat Agraris, Madura 1850-1940, Terj. Mohammad Efendi \& Punang Amaripuja, (Yogyakarta : Mata Bangsa, Cet. I, 2002).

Landy, David, "Sorcery and Witcheraft in Sickness and in Health" dalam Culture, Disease, and Healing, David Landy (ed.), (New York: Macmillan Publishing Co. Inc., 1977).

Rifai, Mien A.,Manusia Madura;Pembawaan, Perilaku, Etos kerja, Penampilan, dan Pandangan Hidupnya, (Yogyakarta: Pilar Media, 2006).

Strauss, C.L., Structural Anthropology, (New York: Basic Bool Inc., 1963).

, The Sorcerer and His Magic: Culture, Disease, and Healing, (ed: David Landy), (New York: Macmillan Publishing Co. Inc., 1977).

Wiyata, A. Latief, Carok; Konflik Kekerasan dan Harga Diri Orang Madura, (Yogyakarta: LKiS, 2000).

---------, Madura yang Patuh?; Kajian Antropologi Mengenai Budaya madura(Jakarta: CERIC-FISIP UI, 2003).

Zola, J.K., "Kebudayaan dan Symptom: Sebuah Analisa mengenai Keluhan yang Diajukan oleh Para Pasien" dalam Manusia, Kebudayaan, dan Lingkungan (ed. Parsudi Suparlan), (Jakarta: Rajawali, 1984). 